\title{
History of Medicine
}

National and international rivalries can intrude into the arena of medical and scientific advances. Editorials and reports published in North American, British, and French medical journals in early 1847 regarding the discovery and initial use of ether anaesthesia illustrate these rivalries. The effects of these opinions and attitudes on the spread of ether anaesthesia are analyzed.

The early history of anaesthesia was marted by the rivalry amongst the various claimants of its discovery. Although William T. G. Morton was generally given the credit, both Charles Jackson and Horace Wells, as well as their respective supporters, disputed this claim for many years. ${ }^{1}$

National and international rivalries may also intrude on scientific and medical discoveries. In the United States, a Philadelphia journal cast aspersions on this new Bostonian development. Despite the fact that anaesthesia was an American development, a lively exchange occurred across the English Channel in the early months of 1847 reflecting a well-established rivalry between Great Britain and France.

\section{Part 1: The Philadelphia-Boston dispute}

The two major nincteenth century medical centres in the United States expressed their rivalry in print. The original report by Bigelow, a surgeon at the Massachussetts General Hospital (MGH), regarding the ether demonstration appeared in the Boston Medical and Surgical Journal of November 18, 1846. ${ }^{2}$ His article stated that the actual substance was a proprietary secret but that it was obvious that it contained ether. He also revealed that William

\section{Key Words}

ANAESTHESIA: history; ANAESTHETICS, INHALATION: ether.

From the Department of Anesthesia, University of Pennsylvania, 509 Gates, Hospital of the University of Pennsylvania, 3400 Spruce Street, Philadelphia, PA 19104.
Morton, a dentist, and Charles Jackson, a chemist, were in the process of obtaining a patent. He justified the patent process stating that the substance was unknown, capable of abuse, and could be put to use for nefarious ends. He explained that Morton had ceded the free use of Letheon (Morton's trade name for ether) to the MGH and he intended to be liberal with the medical profession. In addition, its main use would be in dentistry where patent and secret processes were common. The patent and licensing process would restrict its use to responsible persons.

The cover of the same issue bore the following advertisement: $^{3}$

To Physicians and Surgeons. - The subscriber is prepared to furnish a person fully competent to administer his compound to patients who are to have surgical operations performed, and when it is desired by the operator that the patient should be rendered Insensible to pain. Personal or written applications should be made to $W . T$. G. Morton, Dentist, No. 19 Tremont Row. P. S. Surgeons and Physicians who may wish to witness the effect of this new agent, are respectfully invited to call at my rooms. W. T. G. M.

\section{The Philadelphia response}

The Medical Examiner of Ptiladelphia was quick to publish an editorial in its Deecmber, 1846 issue which attacked the idea of physicians using secret remedies. ${ }^{4}$

From a paper by Dr. H. J. Bigelow... we derive the astounding information that Dr. Warren and Dr. Hayward-men at the very top of our professlon-have allowed Morton to administer his "preparation"-"a secret remedy" for which he has taken out a patent-to patients on whom they are about to operatel

The Medical Examiner equated the use of patent medicines with quackery. 
We cannot close these remarks, without again expressing our deep mortification and regret, that the eminent men who have so adorned the profession in Boston, should have consented for the moment to have set so bad an example... If such things are to be sanctioned by the profession, there is little need of reform conventions, * or any other efforts to elevate the professional character-physicians and quacks will soon constitute one fraternity.

They also stated their belief that the safety of the agent which they assumed was an ether solution of some narcotic, was unknown and there was the potential for grave consequences and that Philadelphia surgeons would be far more cautious in its use.

We are persuaded that the surgeons of Philadelphia will not be seduced from the high professional path of duty, into the quagmire of quackery ... we advise them to consider how great must be the influence of an agent over the nervous system, to render the patient unconscious of pain, - the danger there must necessarily be from such overpowering medication, and if a fatal result should happen to one of their patients, what would be the effect upon their conscience, their reputation and business, and how the practice would be likely to be vlewed by a Philadelphia court and jury?

The final remark will likely strike a responsive chord in the modern North American practitioner. The Medical Examiner also pointed out that despite Morton's intention to be liberal with the medical profession, there was certainly no mention of this in his advertisement.

This editorial was quoted in several other journals including The British American Journal of Medical and Physical Science (Montreal), ${ }^{6-7}$ The New Orleans Journal, ${ }^{8-9}$ and The Annalist (New York) ${ }^{3,10}$ All were in agreement with its sentiments.

\section{The Boston reply}

The Boston Medical and Surgical Journal published the Medical Examiner editorial verbatim on December 16."

\footnotetext{
*Medicine in the United States in the 1840's was going through a transition with the impetus for greater regulation on the practice of medicine being provided by orthodox practitioners Concurrently, there was a medical reform convention organized in 1846 which culminated in the formation of the American Mcdical Association in 1847. A previous convention slated for 1840 never came to fruition. ${ }^{5}$
}

They pointedly added that the Bigelow article had been cited in the Medical News and Library of Philadelphia but with no additional comments. The December 9 issue of the Boston Medical and Surgical Journal contained an article by the surgeon, John Warren, outlining the events leading up to the first use of ether and justifying the action and support of the Boston surgeons. ${ }^{12}$ He reported Morton's plan to present Letheon to the leading hospitals without charge.

A subsequent report in the Boston Medical and Surgical Journal of early 1847 cited the New York Medical and Surgical Reporter in which Dr. C. T. Collins reported performing a mastectomy on January 9,1847 while using ether with excellent results. He supported the idea of the patent. ${ }^{13}$ An accompanying editorial in the Reporter condemned the patent although it did not attack those who used the patent medication. ${ }^{14}$

\section{The final Philadelphia comments}

In April, 1847, the Medical Examiner published a second editorial. ${ }^{15}$ Letheon was now known to be sulphuric ether and numerous reports of its success had arrived. Special credence was given by the Medical Examiner to the case reports of French and British surgeons. The tone of this editorial was more conciliatory but the caveat was added that

\begin{abstract}
... we cannot divest ourselves of the belief that the employment of an agent which is capable of rendering a patient unconscious of pain during the performance of a severe surgical operation must, when carried to that extent, be fraughl with danger-danger the more to be dreaded because it cannot be estimated, owing to the variations in the dose, and the different susceptibilities of those to whom it is administered. Bad effects have repeatedly been witnessed, and even death in a few instances.* The sagacious Velpeau, we perceive, looks upon it with great dlstrust.
\end{abstract}

In a May editorial, although acknowledging extensive successful use of ether, the Medical Examiner added:

\footnotetext{
*The issue of the safety of ether brought up by the Medical Examiner is certainly legitimate. During March, 1847 in England, two deaths occurred postoperatively that were thought to be due to the ether which had been administered. Postmortem findings were unremarkable. ${ }^{16}$ The safety of ether was never a pivotal issue. Chloroform's popularity was quickly tempered by the realization of its polential deadly effects in contrast to ether. ${ }^{17}$ True and perceived dangers of both agents were generally not impediments to their rapid adoption.
} 
Bad consequences are known to have followed the employment of the remedy in repeated instances, but the only wonder is, with such indiscriminate use of so powerful an agent, that the number of accidents has not been greater. ${ }^{18}$

It ended:

Already, in this country, we think we discover a decline of the excitement in relation to it, which prevailed so extensively at the first.

The spread of the news of ether from the United States to Britain and France

The discovery of the anaesthetic effects of ether and the spread of this information are the background for these disputes. After Morton's demonstration at the Massachussetts General Hospital, an account written by Dr. Jacob Bigclow to Dr. Francis Boott reached the shores of Great Britain on December 16, 1846 and was delivered the next day to Dr. Boott. Boott forwarded this information to The Lancet and probably The London Medical Gazette. Ether was administered for the first time on December 19, 1846 at Boott's house. The chronology was fully summarized by Ellis in $1976,,^{19}$ who recently presented evidence of the early arrival in Britain of other correspondence regarding the innovation of ether. ${ }^{20}$

News regarding the new discovery reached France in November. ${ }^{21}$ An American physician studying in France, Francis Willis Fisher (1821-77), received a letter from his former professor of medicine whom he did not name, informing him of this important development. ${ }^{22}$ Fisher approached the surgeon Alfred Vclpcau (1795-1867)* and attempted to persuade him to try the new substance. Velpeau demurred. Fisher, eager to promote ether, tried it on himself in the presence of witnesses. He succeeded only in causing excitement. On December 15, Jobert de Lamballe, another prominent Paris surgeon, invited Fisher to attempt etherisation on one of his patients at the Hôpital St. Louis. Again, Fisher failed because the patient's condition, cancer of the lip, prevented him from applying his mouth tightly to the opening in the glass globe inhaler employed by Fisher. The inhaler was similar to the Morton model but lacked valves. ${ }^{21,23-24}$

\section{Part 2: The Britain-France dispute}

Some joumals on either side of the English Channel pursued aggressive editorial policies. The Medical Times was published weekly in London from 1839 until 1939

*Alfred Velpeau (1795-1867), a noted French surgeon, was one of the first surgeons in France to attempt surgery under ether anaesthesia. ${ }^{25}$
The Annales de Thérapeutique Médicale et Chirurgicale et de Toxicologie was published monthly in Paris from 1843 until 1890. It printed original review articles as well as abstracts of works of interest in the world medical literature.

\section{The first English report}

The Medical Times printed a brief report which appeared on December 26, 1846: ${ }^{26}$

We have been informed that two operations were performed by Mr. Liston, at University College Hospital, on Saturday last. while the patients were under the stupifying [sic] influence of vapour of ether. The one was amputation of the leg the other evulsion of the nail of the great toe. The vapour of ether was inhaled by means of a proper apparatus, and when it had produced its full effect, the operation was speedlly performed. Neither of the patients knew, when they recovered from their stupor, that the operation had been performed. Mr. Liston observed that the vapour of ether had been used for a similar purpose in America, but only in minor operations, such as the removal of tumours, \&c. We hope to have further particulars on this very interesting subject.

\section{The first French response}

The Annales of January, 1847 carried the following report which had slight but significant alterations: ${ }^{27}$

Operations without pain!-An English journal (Medical Times, December 28, [sic] 1846) reports that Mr. Liston, surgeon at the hospital of the University of London, has just performed in his clinic during the past week, two bloody operations (an amputation of the leg and evulsion of the toe nail of the large toe; without causing pain and without the knowledge of the patients, by intoxicating them beforehand, with ether vapour. The vapour was inhaled for some time by means of an apparatus, until coma became manifest. When they awoke they found their operation completed and they declared that they had heard nothing? The author states that this method had already been implemented for the same purpose in America [alterations italicized by this author].

The writer commented:

It is understandable that if this communication is correct, one cannot excessively condemn similar 
conduct. You poison patients to spare them pain? But are you certain that they will awaken afterwards? It would be of greater benefit to have them sleep under an Upas tree, ${ }^{*}$ or render them dead-drunk with the help of a good dose of gin!!

For some time, the English journals have discussed serious operations performed without paln, during mesmerlc sleep. $t$ it is probably to counterbalance these deft sleights of hand of shameless charlatanism that Mr. Liston operated in turn with ether, Sad experiments! Homeopathy and mesmerism shake hands these days in Paris as well as London

\section{The reply from England}

The tone had been set. The Medical Times of January 9 , 1847 was swift to respond: ${ }^{29}$

The following amusing remarks on this subject are extracted from the "Annales de Thérapeutique". We fancy that our friends on the other side of the English Channel are rather annoyed that England should have the priority in the introduction of this valuable surgical acquisition into Europe. We know that much worse experiments are performed in Paris.

The writer reproduced the Arnales article in full and then concluded:

We fancy that we shall very soon hear of similar trials in the most theoretlcal and experimental country in the world-France; that they will then have a different appearance, and be attributed to the pure love of science, 8 rc.

The French rebuttal

This is the response by the Annales of February, 1847:33

In our last issue, we reported under the category of critical facts, the first observations which had

*The Upas tree, Antiaris toxicaria, which grows in Java, yields a poisonous juice. In the eighteenth century, Erasmus Darwin wrote that is could destroy all animal and plant life for a distance of sixteen miles around it. ${ }^{28}$

tWith regard to hypnosis, the Annales probably was referring to three 1846 reports of surgery being performed under a mesmeric trance ${ }^{30-32}$ written by Jamcs Esdaile, MD, an army surgeon stationed in India. They described the use of hypnosis to provide a form of anaesthesia during surgical procedures performed on the natives. The final article contained dcpositions by prominent citizens who had witnessed these events. just been published in London by The Medical Times regarding ether inhalation and we treated it lightly, their report being of a nature so as not to insplre confldence in us. Our criticlsm found support arnong the French surgeons; Mr. Velpeau himself adopted our outlook at the Academy. The Medical Times reproduced our reservation in an ironic and triumphant tone and added the following words: "We presume that our colleagues on the other side of the Channel are angrier that England is the first to introduce this important surgical acquisition to Europe. We know that several bad experiments are being conducted at this moment in Paris ... We presume that we will soon hear of similar trials in the most theoretical and experimental country in the world, France." ... Moreover, if you were at all cognizant of the French spirit, you would know that there is no country where scholars render justice to the truth as France, sometimes even to the detriment of French glory. It only suffices to cite the recent polemic by Arago* in favour of Watt regarding the chemical composition of water, the discovery of which had previously been attributed to Lavoisier.

On December 22, 1846, Jobert de Lamballe attempted with the aid of another American student, to perform surgery under ether but failed. On December 24, he succeeded using an inhaler developed by the instrument maker Charrière. ${ }^{34-35}$

On January 12, Malgaigne reported four cases performed under anesthesia using a nasal inhaler. Velpeau was still skeptical and expressed reservations regarding the safety of ether. Fisher, having received a valved Morton inhaler, successfully administered ether to a patient of Roux at the Hôpital Hôtel Dieu on January 23. The nature of the procedure was not stated. Velpeau also used ether on that day with excellent results utilising the Charrière inhaler. ${ }^{21,23-24,35}$ 'The Annoles de Thérapeutique which had been so caustic in January was far more supportive in its February issue. ${ }^{38}$ It stated that the haughty tone of the British had irked their editors, provoking this response. The numerous successful cases in Paris had well proven the value of ether and now engendered their support.

*The "Water Controversy" was initiated by Dominique François Jean Arago (1786-1853), a French physicist and astronomer. James Watt (1736-1819) was the first to state that water was a compound but he expressed this in terms of the phlogiston theory. Antoine Lavoisier (1743-94) determined the nature of the component atoms in non-phlogiston terms. ${ }^{36-37}$ 


\section{Discussion}

\section{The Yankee scourge}

It appears that ether's being a Boston development did retard its acceptance in Philadelphia. Although ether was first used at the clinic at the Jefferson Medical College on July 19,1847 and at the University of Pennsylvania clinic on October $20,1847,{ }^{39}$ procedures at Pennsylvania Hospital were not performed under ether until $1853 .^{40}$ There was an attempted administration of ether at Pennsylvania Hospital in 1847 but it was aborted by the surgeon. ${ }^{41}$

There werc several rcasons for this impediment to the spread of ether anaesthesia. First, Philadeiphia and Boston were traditional rivals. Initially, the School of Medicine at the University of Pennsylvania was foremost in the United States, being the older and more established institution in comparison with its counterpart at Harvard. But during the nineteenth century, prominent Bostonians studied in Philadelphia and retumed to Boston where they expanded on the training received at Penn. While Philadelphia medicine tended to rest on its laurels, Harvard forged ahead so that by the mid-1800's Boston had taken over the role of the medical mecca. ${ }^{42}$

Personal communications played an important role in the spread of medical knowledge. New developments were taken seriously only on the advice of trusted corresponding colleagues. The news spread to Britain by way of Bigelow's letter to Boott. ${ }^{19}$ In France, Fisher received the news from either Bigelow or Fisher's uncle, John Dix Fisher, who was also on the teaching staff of the medical school at Harvard. ${ }^{43}$ Jackson states that it was the uncle who was the source of the communication. ${ }^{44}$

The lines of correspondence between Philadelphia and Boston were somewhat more tenuous. American medical centres tended to look to Europe rather than each other for news regarding medical progress. ${ }^{45}$ From 1820 to 1860 , hundreds of American physicians went to France for training. ${ }^{46-49}$ With the exception of its use in New York City on December $12,1846,{ }^{49}$ ether was administered in London and Paris at least two weeks before its use in a North American city outside of Boston. ${ }^{50-53}$

Despite its outlook upon France as a medical centre, Philadelphia did not readily adopt ether anaesthesia. There is precedent for this type of dichotomy. Americans who travelled to France during the first half of the nineteenth century were most eager to thoroughly ground themselves in French medical theory but they were disdainful of French therapeutics. French patients were regarded as being constitutionally weaker than their American counterparts due to poverty and malnutrition. Therefore, French therapeutic modalities would not be appropriate if transplanted to the United States because they were specific for their own population. ${ }^{46}$
The Medical Examiner made much of the possible consequences of adverse effects arising from the use of ether. Ether had previously been used as an inhalant for various maladies but the practitioner would desist as soon as dizziness or lighthcadedncss oecurred. ${ }^{2}$ In other words, the administration of ether was being carried into the realm of what were previously considered dangerous side effects. This objection has merit but delaying ether's use until 1853 certainly fell outside the bounds of prudence.

The final objection was to the patent process which involved ether. All the joumals outside of Boston were uniform in their condemnation. ${ }^{3-4,6-10}$ The words "ether" and "Yankee" were intertwined. ${ }^{54}$ The Yankee mentality was associated with rapaciousness and an eagemess for pecuniary reward in cautious Philadelphia and especially in the South. ${ }^{55}$ Even Liston while praising ether termed it a "Yankee dodge. " ${ }^{56-57}$ Pernick ${ }^{58}$ has meticulously documented all of these factors affecting the spread of ether anaesthesia in the United States.

\section{British-French rivalry}

Acceptance in France was widespread and enthusiastic once the initial reluctance to use the agent was overcome. The only persistent opponent was Magendie, the prominent physiologist. His objections were based on moral grounds. He found the idea of the patient being converted into an unthinking "cadaver" abhorent and demeaning. ${ }^{59}$ Some equated the use of ether with inebriation and its associated immorality. ${ }^{27}$ Whether the reception of ether would have been as enthusiastic if it had been an English development is a moot point. The French did readily accept the Scottish innovation of chloroform. ${ }^{60}$

The Anglo-French rivalry was an ambivalent thing. It has been extensively discussed by Faber. ${ }^{61}$ Ironically, the first part of the nineteenth century saw a large number of British medical students coming to France to study pathology and hospital medicine, areas where the French were paramount. ${ }^{62}$ Such individuals as Astley Cooper, A. V. Waller, and Thomas Hodgkin all made the pilgrimage ${ }^{63}$ Although the British students were enthusiastic, some tension existed between the French and British students vying for space at the various lectures and rounds. The British students were economically better off than their French counterparts. Feelings reached such a level that intercession by the British Foreign Secretary was required. ${ }^{62}$ The rivalty between the two groups coexisted with the obvious admiration for French ideas and individual professors.

\section{Conclusions}

Progress in the use of ether was affected by regional rivalries. Ironically, Paris and London were quick to adopt anaesthesia despite some minor squabbling. A pragmatic attitude prevailed. In contrast, North American 
medical communities beyond Boston were slower in their acceptance. This was especially true of Philadelphia partly due to its inherent conservatism and partly because of its reluctance to accept the "Yankee dodge."

\section{Acknowledgements}

I would like to thank Tom Horrocks and the staff of the library of the College of Physicians of Philadelphia and Richard J. Wolfe of the Francis A. Countway Library of Medicine for their assistance.

\section{References}

1 Ludovici L. The Discovery of Anaesthesia. New York: Thomas Y. Crowell Co., 1961 .

2 Bigelow HJ. Insensibility during Surgical Operations Produced by Ether. Bost Med Surg J 1846; 35: 309-17.

3 Anonymous. Insensibility during Surgical Operations Produced by Inhalation (Editorial). Annalist 1847; 1: 137-41.

4 Anonymous. Insensibility during Surgical Operations Produced by Inhalation (Editorial). Medical Examiner 1846; 2: 719-20.

5 Fishbein M. A Histoty of the American Medical Association 1847-1947. Philadelphia: W.B. Saunders Co., 1947: $19-26$.

6 Anonymous. Insensibility Produced during Surgical Operations Produced by Inhalation (Report). Br Am J of Med Phys Sci 1847; 2: 247-8.

7 Anonymous. Inhalation of Sulphuric Ether Vapour (Editorial). Br Am J of Med Phys Sci 1847; 2: 304-5.

8 Anonymous. Insensibility during Surgical Operations Froduced by Ether (Report). New Orleans Med Surg J $1847 ; 3: 555$.

9 Anonymous. The Letheon (Editorial). New Orleans Med Surg J 1847; 3: 687 .

10 Anoymous. The Letheon (Editorial). Annalist 1847; 1: $188-90$.

11 Anonymous. Insensibility during Surgical Operations Produced by Inhalation (Editorial). Bost Med Surg J 1846; 35: 413-4

12 Warren JC. Inhalation of Ethereal Vapor for the Prevention of Pain in Surgical Procedures. Bost Med Surg J 1846; 35: 375-9.

13 Aronymous. Insensibility by the Inhalation of the Letheon (Editorial). Bost Med Surg J 1846; 35: 542.

14 Anonymous. Letheon (Editorial). NY Med Surg Rep 1847; 2: $52-4$.

15 Anonymous. Insensibility during Surgical Operations (Editorial). Med Exam 1847; 4: 229-30.

16 Duncum BM. The Develepment of Inhalation Anaesthesia. London: Oxford University Press, 1947: 164-5.

17 Snow J. On Chloroform and Other Anaesthetics. London: John Churchill, 1858: 362.
18 Anonymous. Inhalation of Sulpburic Ether (Editorial) Med Exam 1847; 4: 290.

19 Ellis $\mathbf{R H}$. The Introduction of Ether Anaesthesia to Great Britain. Anaesthesia 1976; 31: 766-77.

20 Ellis RH. The News of Anaesthesia Spreads to Britain (Abstract). Second International Symposium on the History of Anaesthesia. London. July 20-23, 1987: 003.

21 Fisher FW. The Ether Inhalation in Paris. Bost Med Surg J 1847; 36: 109-13.

22 Harringron TF. The Harvard Medical School. Vol. 3. New York: Lewis Pub Co., 1905: 1476.

23 Hodges RM. A Narrative of Events Connected with the Introduction of Sulphuric Ether into Surgical Use. Boston: Little Brown, 1891: 68-9.

24 Trent JC. Surgical Anesthesia 1846-1946. J Hisst Med All Sci 1946; 1: 505-14.

25 Talbott J. A Biogtaphical History of Medicine. New York: Grune and Stratton, 1970: 551-3.

26 Anonymous. Operations without pain (Report). The Medical Times 1846; 15: 251

27 Anonymous. Opérations sans douleur (Report). Annales de Thérapeutique 1847; 4: 399.

28 The Compact Edition of the Oxford English Dictionary Vol. 2. Oxford: Oxford University Press, 1971: 3561.

29 Aronymous. (Editorial). The Medical Times 1847; 15: 291.

30 Esdaile J. Alleged painless operation by mesmerism. The Medical Times 1846; 15: 32-3.

31 Esdaile J. Alleged painless operation by mesmerism. The Medical Times 1846; 15: 68-9.

32 Esdaile J. Alleged painless operation by mesmerism. The Medical Times 1846; 15: 145-7

33 Anonymous. Petite réponse à un journal anglais à propos de l'éther (Edjtorial). Annales de Thérapeutique 1847; 4: 437

34 Neveu $R$. The Introduction of Surgical Anesthesia into France. J Hist Med All Sci 1946; 1: 607-10.

35 Davison MHA. The Evolution of Anaesthesia. Altrincham: John Sherrat and Son, 1965: 117-8.

36 Partington J. A History of Chemistry London: Macmillan and Co., 1962: 325-38, 344-62, 436-53.

37 Hahn R. Arago, Dominique François Jean. In: Gillispie C (Ed). Dictionary of Scientific Biography. Vol. 1. New York: Charles Scribnex's Sons, 1970: 200-3.

38 Anonymous. L'éther sulfurique (Editorial). Annales de Thérapeutique $1847 ; 4: 416-20$.

39 Anonymous. (Appendix) Transac AMA 1848; 1: 220-1

40 Pernick MS. A Calculus of Suffering. New York: Columbia University Press, 1985: 201.

41 Packard FR. The Conquest of Surgical Pain. Philadelphia: American Philosophical Society, 1940: 37-8.

42 Eaton LK. Medicine in Philadelphia and Boston, 1805 1830. Pa Mag Hist Biog 1951; 75: 66-75. 
43 Wolfe RJ. Personal Communication. Countway Library of Medicine.

44 Jackson CT. A Manual of Ethenzation. Boston: JB Mansfield, 1861: 57.

45 Pernick MS. A Calculus of Suffering. New York: Colımbia University Press, 1985: 204-5.

46 Warner JH. The Selective Transport of Medical Knowledge: Antebellum American Physicians and Parisian Medical Therapeutics. Bull Hist Med 1985; 59: 213-31.

47 Jones RM. American Doctors and the Parisian Medical World 1830-40 (concluded). Bull Hist Med 1973; 47: 177-204.

48 Jones RM. American Dactors and the Parisian Medical World, 1830-40. Bull Hist Med 1973; 47: 40-65.

49 Anonymous. The "Letheon" at the New-York Hospital (Report). Annalist 1846; 1: 166-8

50 Pope CA. Inhalation of Ethereal Vapor-Operations Performed under its Influence. St Louis Med Surg J 1847; 4 : $531-4$.

51 Anonymous. Inhalation of Sulphuric Ether (Report). New Orleans Med Surg J 1847; 3: 818-2I.

52 Maliby $I R$. The Origins of Anaesthesia in Canada (Abstract). Second International Symposium on the History of Anaesthesia. London. July 20-23, 1987:008.

53 MacDougall JA. The Earliest Ether Anaesthetic in British North America - a First for Saint John, New Brunswick? Can J Anaesth 1987; 34: 496-504.

54 Pernick MS. A Calculus of Suffering. New York: Columbia University Press, 1985: 202.

55 Olson JS. The Ethnic Dimension in American History. New York: St. Martin's Press, 1979: 59-61.

56 Curtis $\boldsymbol{R H}$. Triumph over Pain. New York: David McKay and Co., 1972: 67.

57 Nulund SB. The Origins of Anesthesii. Birningham: The Classics of Medicinc Library, 1983: 85.

58 Pernick MS. A Calculus of Suffering, New York: Columbia University Press, 1985: 201-6.

59 Olmsied JMD. François Magendie. New York; Schuman's, 1944: 244-7.

60 Durcum BM. The Development of Inhalation Anaesthesia. London: Oxford University Press, 1947: 225.

61 Faber $R$. French and English. London: Faber and Faber, 1975.

62 Maulitz RC. Channel Crossing: The Lure of French Pathology for English Medical Students, 1816-36. Bull Hist Med 1981; 55: 475-96.

63 Ackerknechr EH. Medicinc at the Paris Hospital 17941848. Baltimore: The Johns Hopkins Press, 1967: 192-3.

\section{Résumé}

Les rivalités internationales et nationales peuvent influencer le progrès médical et scientijlque. Les éditoriaux et les rapports publiés dans les revues Nord Américaines, anglaises et françaises au début del l'année 1847 conternant la découverte et l'urilisation de l'antesthésic à l'êther illustrent ces rivalités. Les effets de ces opinions et antitudes sur la propogation de l'anesthésie à l'éther sont analysés. 